\title{
SOME ASPECTS OF PROTEIN DIGESTION AND ABSORPTION IN HEALTH AND DISEASE
}

\author{
C. W. Crane, B.Sc., M.B., B.S., A.R.I.C. \\ Senior Research Associate in Medicine and Hon. Lecturer in Medicine, Wellcome Research Wing, Department of Medicine, \\ University of Birmingham and Queen Elizabeth Hospital, Birmingham, I 5
}

THE study of protein digestion and absorption has occupied the attention and interest of physiologists and biochemists for over 150 years since the classical experiments of Spallanzani and the epochmaking discovery by Beaumont of the digestive properties of the gastric juice of his patient, Alexis St. Martin. It has been demonstrated by nitrogen balance experiments that the overall mechanism in man is an extremely efficient one. Reifenstein, Albright and Wells (I945) fed human subjects increasing amounts of protein (from 20 to 250 g. a day), but found that the daily fæcal nitrogen excretion remained substantially the same level of between $I$ and $2 \mathrm{~g}$. Evidence regarding the origin of the fæcal nitrogen from studies on patients undergoing a prolonged fast or receiving diets containing negligible quantities of protein (Lusk, 1928) strongly suggest, however, that a large proportion of the fæcal nitrogen is derived from endogenous sources, so that the efficiency of assimilation at levels of intake of protein of $250 \mathrm{~g}$. per day is thus greater than $95 \%$.

Yet Fisher, writing in 1954, pointed out that precise information on a number of important details in these events was still lacking, among them the rates of digestion and absorption of protein and the form in which the split products are absorbed by the intestinal mucosa. The rate of breakdown of proteins in vivo has long been known to be much faster than occurs in vitro by the successive actions of gastric and pancreatic enzymes and 'erepsin' and Fisher discusses at some length the evidence for concluding that proteins may not be degraded completely to single aminoacids before absorption. There is some recent evidence for believing that dietary proteins are absorbed from the gut unchanged. Bangham and Terry (1957) and Bangham, Ingram, Roy, Shillam and Terry (1958) have shown that plasma proteins may be absorbed unchanged from the gut in newborn rats and calves, while Dent and Schilling (I949) were unable to show any rise of aminoacids in the portal blood of dogs receiving homo- logous serum protein by mouth in contrast to the high values found when normal dietary proteins were given. In contrast Kekwick (I959) concluded that the evidence for the absorption of antibodies by newborn babies from maternal colostrum was not very strong. However, Wilson and Walzer (1935) from their work claimed that babies could absorb whole egg white and Gruskay and Cooke (1955) reported that after bouts of diarrhœa in young children an increase as much as fivefold in the absorption of this protein was possible. More recently Parish, Barrett, Coombs, Gunther and Camps (I960) have claimed that the serum of babies fed cows' milk may contain antibodies to the milk proteins. Thus it appears certain that if whole protein is absorbed unchanged then this is confined to special circumstances either during the neonatal period of life or in association with disease, but, in any case, the amounts must be extremely small. It is not yet certain, however, whether the conclusions apply in respect to homologous serum plasma protein. If proteins are not degraded completely to aminoacids prior to absorption and larger fragments are absorbed into the mucosa, evidence for the presence of large quantities of circulating peptides in the blood in the post-absorptive phase after giving protein by mouth has not yet been demonstrated. For example, Dent and Schilling (1949) were unable to show any significant concentration of peptide in the portal blood of their experimental dogs after protein feeding.

\section{Methods for Investigating Protein Digestion and Absorption}

Although nitrogen balance experiments may give useful information regarding the overall loss or gain of nitrogen by the body under a variety of conditions, such studies provide no measure of the rates of digestion and absorption of protein. Clearly many of the experimental techniques used in animal work (e.g. Wright and Wynn, 195I; Gupta, Dakroury and Harper, 1958; Geiger, 
Human and Middleton, 1958) cannot be applied to human subjects. The occurrence of patients with intestinal fistulæ such as described by Kuroda and Gimbel (1954) and suitable for absorption studies is extremely rare, while results of experiments with patients having portal collaterals on the abdominal wall and which can be sampled at intervals after giving protein by mouth were found by Bean, Franklin, Embrick and Daum (I95I) to be difficult to interpret. Techniques which have been used with some success in human subjects fall into two main groups: those which involve sampling the contents of the lumen of the gut at given levels and those which measure changes in the concentration of constituents of the peripheral blood. McGee and Emery (1940) studied the digestion and absorption of solutions of casein and gelatin by sampling the contents of segments of the jejunum blocked distally by inflated balloons, while Nasset and Davenport (1954) investigated the proteolysis of lactalbumin in the stomach by sampling the gastric contents. The most successful of the techniques so far has been that devised by Blankenhorn, Hirsch and Ahrens (1955), in which a fine polythene catheter is passed along the entire gut, enabling sampling at a number of given levels. This method has been used most successfully by Borgström, Dahlqvist, Lundh and Sjövall (1957) to study the digestion and absorption of carbohydrate, fat and protein from a number of human subjects and to acquire a great deal of useful information. A similar technique has also been used by Lundh (1958), who investigated a series of patients with malabsorption following partial gastrectomy.

The other main type of study measures thanges in amino-acid concentration in the peripheral venous blood after the ingestion of a standard quantity of protein or the appearance in the blood of an isotopic tracer after giving a dose of labelled protein. Free and Leonards (1944), using unlabelled protein, compared the times to reach maximum amino-acid concentration in normal subjects ingesting meat, whole blood and casein hydrolysate, while West, Wilson and Eyles (1946) followed the blood amino-nitrogen levels in normal children and those with deficient pancreatic function after giving gelatin and casein. Christiansen and Schwachman (1949) refined this technique and measured the changes in concentrations in the plasma of a specific amino-acid, glycine, after feeding gelatin to both normal persons and those with pancreatic fibrosis.

Other workers have used the rates of appearance of radioactive tracers in the peripheral blood after feeding isotopically-labelled protein. Lavik, Matthews, Spector and Friedell (1952) administered ${ }^{131}$ I-labelled casein to children suffering from pan- creatic disorders, while Chinn, Lavik, Babb Buckaloo, Stott and Abbott (1953) fed ${ }^{131}$ I-labelleco albumin with a meal of gelatin to normal subjects $\cong$ Freeark, Kozoel and Meyer (1957) and Polachek $\vec{c}$ Cope, Williard and Barnes (I959) have made? extensive studies on normal subjects and patient\$ with pancreatic lesions using labelled albumino along with unlabelled gelatin. More recently ${ }^{35} \mathrm{~S}$ - and ${ }^{32} \mathrm{P}$-labelled proteins have been used to study problems of digestion and absorption in patients after gastrectomy by Nakayama, Ohtsuka, Kuvaishi, Koshibu, Arima, Fukushima, Nakagami and Fuse (1958). These workers have $\vec{\omega}$ attempted to simulate normal feeding in theiro experiments by administering their test substanceso along with a meal of bread, butter and egg.

Compared with radioactive tracers, the stable w isotopes have, up to the present, not been usedis extensively in problems of clinical interest. As far $₫$ as the stable isotope of nitrogen, ${ }^{15} \mathrm{~N}$, is concerned, $\underset{+}{ }$ besides freedom from possible hazards of radiation, $v$ its use would be expected to provide more direct? information regarding the digestion and absorption of protein and subsequent metabolism of ingested nitrogen by the body, and White and Parson (1950) and Sharpe, Lassen, Shankman, Gebhardt and $\bar{O}$ Hazlet (1956) have used yeast protein so labelled to study some aspects of protein metabolism क्षी human subjects. Crane and Neuberger (1960, I96ob) have shown that the time to reach maxos. mum labelling of both urinary ammonia and urea in samples of urine passed at frequent intervals after administering the protein by mouth may be used to investigate the digestion and absorption of protein in normal subjects and in patients suf- $\varrho$ fering from adult cœliac disease.

To some degree criticism can be levelled at all the methods of investigation that have been mentioned. It is difficult to be absolutely certain, for example, that the presence of a sampling tube lying within the gut does not produce abnormal peristalsis, while experiments involving sampling of the $\frac{3}{3}$ contents from a segment of small bowel closed distally by a balloon must be regarded as non- $\frac{\rho}{\beta}$ physiological. In those studies in which changes in peripheral-blood amino-nitrogen are measured $\frac{5}{5}$ after ingesting a quantity of test substance it is $\frac{D}{0}$ necessary to be sure that these bear some relation with respect to time to the changes occurring in the N portal blood. In patients suffering from malnutrition these differences may be considerable. The rate of digestion of a test protein will be $\mathrm{N}$ dependent upon whether considerable denaturing has occurred during its preparation and whether

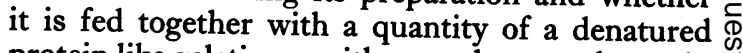
protein like gelatin, or with an undenatured protein like skim milk. The fact that these rates may be appreciably different has been used by Bocci (196I) 
to determine the extent of denaturing of ${ }^{131} \mathrm{I}$ labelled gamma globulins. Work with radioactive tracers involves usually the measurement of activity of samples of whole blood and no attempt is made to separate and identify specifically-labelled aminoacids. Provided that one can be sure that no free iodide is present in the sample, the method is probably sufficiently accurate for work with ${ }^{131}$ Ilabelled proteins, but when ${ }^{35} \mathrm{~S}$ and ${ }^{32} \mathrm{P}$ tracers are used allowance must be made for the radioactivity of secondary products occurring in the plasma from the metabolism of these substances within the body.

The use of ${ }^{15} \mathrm{~N}$-labelled protein offers advantages in that the isotope appearing in the urinary ammonia and urea is almost certainly derived from all the amino-acids entering the body and that small quantities can be given alone or mixed with other proteins. The technique can also be used in ill patients where intubation or large amounts of protein by mouth would not readily be tolerated. Furthermore, the ${ }^{15} \mathrm{~N}$ excreted in the urine and fæces allows assessment to be made of the amount of tracer retained under different conditions.

\section{The Digestion and Absorption of Protein in Normal Subjects}

Hydrolysis of dietary protein (warmed, masticated and moistened with saliva) begins in the stomach by the action of pepsin producing a complex mixture of high-molecular weight peptides often referred to as 'peptones'. The extent of this initial proteolysis will depend upon a number of factors: the availability of hydrochloric acid and pepsin, the type of protein eaten, and the rate at which the stomach empties, and would therefore be expected to vary considerably from person to person and from meal to meal in the same person. For example, if the consumption of a meal is rapid, a greater dilution of enzymes and buffering of the available hydrochloric acid would be expected, while the presence of fat and a state of hunger would both influence the rate at which the stomach empties. Lastly, a protein denatured by thorough cooking would be attacked more readily by proteolytic enzymes than one only partially denatured, for example, underdone meat. Thus any general statement regarding the extent of gastric proteolysis must take into account these features. Cathcart (192I) suggested under normal conditions that the degree of gastric digestion was unimportant and Borgström, Dahlqvist, Lundh and Sjövall (r957) concluded that after feeding a meal of corn oil, dextrose and skim milk powder not more than $15 \%$ of an admixed tracer dose of ${ }^{131}$ I-labelled albumin was hydrolysed in the stomach of normal subjects. The assumption by these authors that this figure applies also to the milk powder must be accepted with some reserve, since there may be considerable differences in the rate of proteolysis of milk protein and the albumin. Using cooked pig's heart as the test protein, Elsom, Chornock and Dickey (1942), on the other hand, found considerable proteolysis in the stomach of their subjects. Whether a proportion of these large peptides may be further hydrolysed and absorbed by the stomach mucosa is not at present definitely known, but it is of some importance that Linderstrom-Lang and his colleagues (1952) were able to find peptidases capable of hydrolysing small synthetic peptides in the fundal cells of the pig's stomach. The observation of Nasset and Davenport (1954) that after one hour the concentration of free amino-acid in the stomach contents after feeding lactalbumin had risen tenfold is also of some interest, but these authors were unable to exclude the regurgitation from the duodenum of powerful pancreatic enzymes. However, it is unlikely that significant proteolysis could have occurred from the action of these enzymes owing to the low $\mathrm{pH}$ of the gastric contents. Following the emptying of the stomach contents in small portions over about four hours, the Swedish workers found that a three- to fivefold dilution took place in the duodenum and that extensive digestion ( 50 to $60 \%$ ) resulted from the action of the pancreatic enzymes. The absorption of protein was almost complete during the passage through the proximal $100 \mathrm{~cm}$. of the jejunum (maximum absorption occurring within the second hour), but that about $10 \%$ of the test protein could be recovered unchanged from the lowest portion of the small intestine. These workers suggested, therefore, that some dietary protein is normally digested and absorbed in the large bowel.

The $\mathrm{pH}$ of the contents of various sections of the gut were also measured. Over the first three hours the $\mathrm{pH}$ of the gastric contents were found to be between 3 and 4 , while that of the small intestine was between 6 and 8 , the latter values being reached only in the ileum. In view of the rapid digestion of the protein in the upper jejunum it is surprising that these values are so far removed from the $\mathrm{pH}$ optima determined experimentally for pepsin and the pancreatic enzymes.

Recently Taylor (1959a) has demonstrated that gastric juice from normal subjects contains pepsin with maximum activities occurring between $\mathrm{pH}$ I.6 to 2.4 and also between $\mathrm{pH}_{3.3}$ to 4 . Measurement of proteolysis in the lower ranges of $\mathrm{pH}$ alone therefore underestimates the true extent of breakdown of which this enzyme is capable.

Estimates of the overall rates of digestion and absorption of protein have been made by a number of workers and, as would be expected, these show variations according to the type and quantities of 
protein fed. Free and Leonards (1944) found that the maximum amino-acid concentration occurred at three and four hours respectively after the administration of a litre of blood and $400 \mathrm{~g}$. of meat to normal subjects. In studies of normal children, West, Wilson and Eyles (1946) found that these maxima occurred at $I_{2} \frac{1}{2}$ hours after feeding either casein or gelatin in amounts equivalent to $1.7 \mathrm{~g} . / \mathrm{kg}$. body weight. Using radioactive techniques, Lavik and others (1952) reported maximum radioactivity of venous blood within three hours after a test meal of $0.5 \mathrm{~g}$. of gelatin/kg. body weight admixed with ${ }^{131}$ I-labelled albumin, while Chinn and others (1953) have found similar results. Nakayama and others (1958), on the other hand, showed maximum concentrations of radioactivity in the peripheral blood were delayed to between six and seven hours in normal subjects receiving test doses of ${ }^{35} \mathrm{~S}-$ and ${ }^{32} \mathrm{P}-$ labelled proteins along with a meal consisting of $86 \mathrm{~g}$. of carbohydrate, $30 \mathrm{~g}$. of fat and $26 \mathrm{~g}$. of protein. Using much smaller quantities (circa $2 \mathrm{~g}$.) of ${ }^{15} \mathrm{~N}$-labelled yeast protein in fasting subjects (Fig. I).

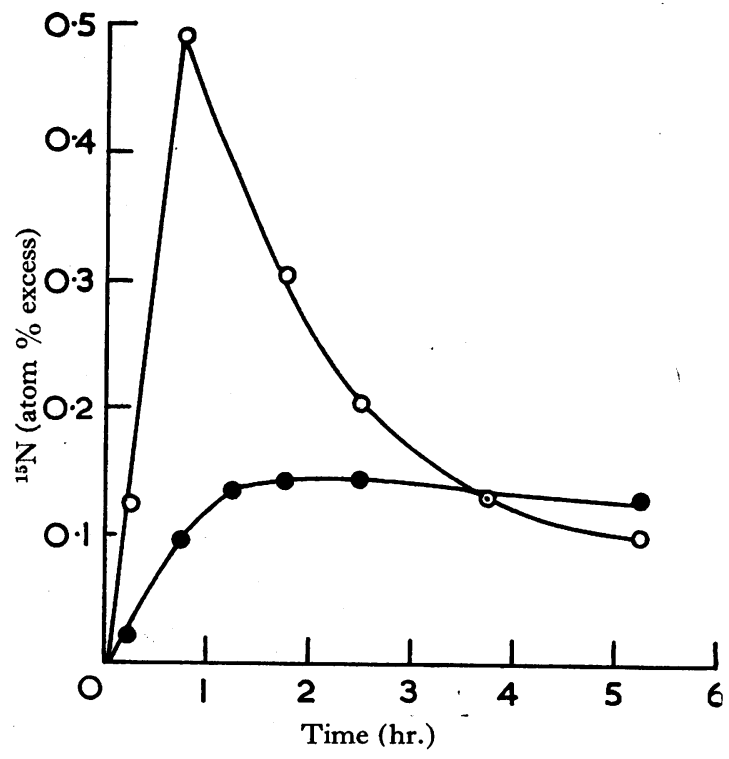

FIG. I.-Comparison of the rate of change of ${ }^{15} \mathrm{~N}$ labelling of ammonia (-o-) and urea (-๑-) in urine after giving whole yeast protein to a fasting normal subject equivalent to $0.8 \mathrm{mg} .{ }^{15} \mathrm{~N} / \mathrm{kg}$. body weight. Values are plotted at the mid-points of the collection intervals.

Crane and Neuberger (1960a) showed that digestion and absorption were extremely rapid, urinary ammonia being maximally labelled at about 45 minutes after administration and urinary urea at about 75 minutes. Little difference could be detected between the rates of digestion and absorp-

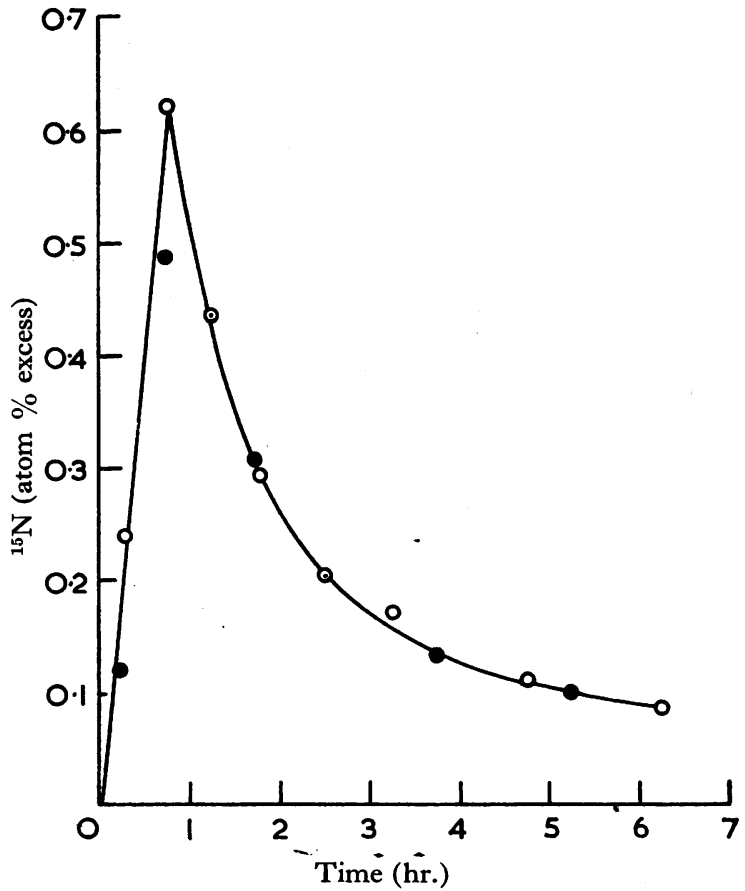

FIG. 2.-The isotopic labelling of urinary ammonia after giving whole yeast protein (-๑) and yeas protein hydrolysate (-o-) to a fasting normato subject in amounts equivalent to $0.8 \mathrm{mg} .{ }^{15} \mathrm{~N} / \mathrm{kg}$. body weight. Values are plotted as for Fig. I.

tion of whole protein and the abosrption of an equivalent amount of water-soluble enzymically hydrolysed labelled yeast protein and it was estimated that under the conditions of study the hydrolysis of the protein in the intestines retarded the overall absorption by at the most 10 minutes (Fig. 2). Similar conclusions were reported by Janney (1915), who measured the urinary output of nitrogen and glucose in phloridzinized dogs after administering whole protein and protein hydrolysate and by Gupta, Dakroury and Harper (1958), who examined the rates of disappearance of protein and amino-acid mixtures from intestines of rats. When, however, the ${ }^{15} \mathrm{~N}$-labelled material was mixed with milk powder equivalent to $0.4 \mathrm{~g}$. of protein $/ \mathrm{kg}$. body weight there was considerable delay in the overall digestion and absorption of this protein, maximum labelling of the urinary ammonia and urea occurring at about $2 \frac{1}{2}$ and three to four hours respectively, values which are in agreement with those already discussed. These findings, together with those of Borgström, Dahlqvist, Lundh and Sjövall (1957), allow of the conclusion that protein digestion and absorption is a very rapid process in the upper part of the alimentary canal and that the overall rate is controlled mainly by gastric emptying. The very rapid hydrolysis 
of the protein is likely to be due to the very high concentrations of trypsin and chymotrypsin which are found in the small intestine. Borgström and others (1957) found values between 200 to 800 $\mu \mathrm{g} . / \mathrm{ml}$. within a short time of giving a test meal. When yeast protein was digested in vitro with concentrations of these enzymes equivalent to about $400 \mu \mathrm{g} . / \mathrm{ml}$., Crane and Neuberger (I960a) estimated that more than $50 \%$ of the protein was converted into peptides soluble in trichloracetic acid within ro minutes, and it is likely that the conversion of protein to peptides is also a very fast process in vivo. It has already been mentioned that there is considerable uncertainty regarding the form in which the products of digestion of proteins are absorbed by the mucosa. Experiments such as those devised by Wright and Wynn (195I), which demonstrate the presence of both free aminoacids and peptides in the upper intestine after feeding a protein meal to dogs, do not allow conclusions to be reached regarding the amount of protein already absorbed either in the form of peptide or as amino-acids, or whether the peptides are derived mainly from the dietary protein or from the breakdown of endogenous protein secreted within the lumen of the gut. Newey and Smyth (1959), in animal experiments, have shown that simple peptides are hydrolysed inside the mucosal cells. It is reasonable to assume that larger peptides may be similarly degraded by a mixture of peptidases which Wright, Jennings, Florey and Lium (1940) have shown to be essentially intracellular enzymes. Rapid digestion of dietary proteins which has been observed can therefore be regarded as mainly due to the action of high concentrations of pancreatic enzymes, the chief products of which are peptides, which are in turn further hydrolysed to amino-acids after absorption into the mucosal cells. There is further evidence for these conclusions: it is known from studies such as that of Hokin (I95I) that for protein synthesis to occur all the requisite aminoacids must be present at the same moment and that the body is unable to store quantities of aminoacids for any length of time. Thus Geiger (1947) showed that supplementing a diet deficient in essential amino-acids by giving the missing aminoacids several hours later failed to promote growth in animals. However, addition of pure aminoacids to diets deficient in these substances which cause cessation of growth led Rose to the classic discovery of the essential nature of a group of amino-acids. More recently this type of experiment has been extended to human subjects. Gomez, Ramos-Galvan, Cravioto and Frenk (1958) and Scrimshaw, Brissani, Behar and Viteri (1958) have both reported increase in weight together with nitrogen retention in children fed diets poor in lysine and tryptophan, when supplemented with pure amino-acids. From these studies it is difficult to escape the conclusion that digestion and absorption of dietary proteins proceed at rates comparable with the rates of absorption of pure amino-acids.

A further point of interest in this work is the contribution made by protein from endogenous sources. Nasset and his colleagues (see Nasset 1957 for review) in a series of experiments claimed that sufficient endogenous protein is secreted into the gut during digestion to exert a marked influence on the composition of the amino-acids absorbed from the gut. Although some of their conclusions have been questioned by Geiger and his colleagues (1958), it is certain that a considerable quantity of endogenous protein is turned over in the intestine in the form of enzymes, mucus, shed mucosal cells and possibly plasma protein. Mention has already been made of the high concentrations of pancreatic enzymes which are secreted into the small intestine, but Avakian (196I) found that trypsin was rapidly inactivated by incubation with intestinal juice at $37^{\circ} \mathrm{C}$., although chymotrypsin was more stable. The turnover of the mucosal cells in animals has been estimated at about 24 hours (Leblond and Stevens, 1948). If the figures for human mucosa are comparable, the addition of endogenous protein to the gut must be considerable and may well be of the order of the 50 to $100 \mathrm{~g}$./day estimated by Nasset Information concerning the breakdown and ab-? sorption of protein in the large intestine is lacking. Borgström and others (1957) estimated from their studies that $10 \%$ of dietary protein remained unabsorbed by the time a test meal had reached the large intestine and concluded that about $10 \%$ of dietary protein is normally degraded and absorbed there. The work of Reifenstein and his colleagues (1945) on the absorption of diets containing large amounts of protein has already been mentioned. In those studies in which $250 \mathrm{~g}$. of protein were fed daily to human subjects a total of $25 \mathrm{~g}$. of dietary protein would thus be expected to be digested and absorbed by the colon, a quantity equal to between a quarter and one-third of the normal daily intake. This suggests that the estimate by the Swedish workers is too high. On the other hand, it is possible that some of the intestinal enzymes at least, reaching the large intestine, may escape digestion, since Avakian (196r) records that ${ }^{131}$ I-labelled protein can be recovered unchanged after 24 hours in the human rectum.

\section{The Effect of Gastrectomy on Protein Absorption}

The success of partial gastrectomy in the treatment of peptic ulcer in the last 40 years, which in general rarely produces catastrophic upsets in 
nutrition, has been responsible no doubt for the general belief that protein digestion in the stomach is not really essential. The amount of proteolysis produced by pepsin on a variety of dietary proteins in vitro (Fisher, 1954) is not usually marked, but Cathcart (I92I), summarizing earlier views on this point, suggested that the initial action of pepsin on dietary proteins was nevertheless important for the subsequent proteolysis by the pancreatic enzymes. The recent work of Taylor (1959a and 1959b) shows that the true extent of gastric proteolysis is underestimated if measured only at $\mathrm{pH} \mathrm{2}$, and has demonstrated that in patients with pernicious anæmia, activity is present at higher $\mathrm{pH}$ values.

When the details of a large series of patients with adequate follow-up after partial gastrectomy were studied, it became clear that a large majority of the patients had lost weight and further studies (see Lundh, 1958, for review) showed that weight loss was greater in Billroth II operations than with Billroth I and that steatorrhœea and increased fæcal nitrogen losses were greater in the former operation. In patients with total gastrectomy these findings were shown to be more marked and more persistent. A large amount of work on gastric proteolysis following gastrectomy has shown that in general the extent of digestion is impaired by the increased rates of emptying of the stomach remnant and the reduced amount of acid and pepsin available, but studies on pancreatic function following gastrectomy have led to conflicting results. Under normal conditions secretin and pancreozymin which stimulate pancreatic secretion are released from the duodenum by the passage of contents from the stomach. Nakayama and his colleagues (1958), using ${ }^{32} \mathrm{P}$ and ${ }^{35} \mathrm{~S}$-labelled proteins, have shown that the rate of absorption is lower, and the fæcal excretion of isotope greater, in patients after total gastrectomy than in normal subjects. The absorption of their test material was more effective after œsophagealduodenal anastomosis compared with œsophagealjejunal anastomosis.

The changes in this mechanism resulting from gastrectomy (Annis and Hallenback, 1952) were studied in dogs after Billroth I and II operations and results showed that there was marked diminution of pancreatic secretion during the ingestion of cooked meat although response to secretin was nevertheless normal. Using ${ }^{131}$ I-labelled proteins a number of investigations, for example those of Babb, Chinn, Stitt, Lavik, Levey, Kreiger and Abbott (1953), have shown that there may be rapid increases in the radioactivity of the plasma after Billroth II operations, but a more slow rise and more prolonged activity in patients with Billroth I operations, when ${ }^{131}$ I-labelled albumin was used. Lundh (1958), using the intubation techniques of Blankenhorn, Hirsch and Ahrens (1955), studied a large series of patients after gastrectomy. In patients with Billroth I type of operation he found gastric emptying to be more rapid than with Billroth II, but in both groups there was a very rapid passage of a test meal to the distal parts of the small intestine and also evidence of defective digestion. Concentrations of trypsin in the lumen of the gut were found to be low and in a number of samples no activity was found in patients with the Billroth II type of gastrectomy. In Billroth I patients trypsin was mixed with a test meal, but the poor mixing in Billroth II patients was explained by the lack of co-ordination of pancreatic secretion following gastric emptying. The conclusion that the poor mixing of protein with pancreatic enzymes was a more important factor than rapid intestinal passage after gastrectomy was based upon the disappearance of ${ }^{131}$ I-labelled albumin from the small intestine.

It has already been pointed out that the rates of digestion of denatured and native proteins differ markedly and the assumption therefore that the proteins of the normal diet behave in the same manner as albumin remains to be proved.

Only one patient with a sub-total gastrectomy has been investigated with ${ }^{15} \mathrm{~N}$-labelled yeast protein, so far. After feeding ${ }^{15} \mathrm{~N}$-labelled yeast protein to a patient who underwent an operation? three years previously for a three-quarter resection of the stomach for suspected carcinoma and who presented with a steatorrhœa of an average of I I gm. of fat together with 2 to $3 \mathrm{gm}$. of nitrogen per day, it has been found that the rate of uptake of the protein was within normal limits. When the experiment was repeated and an amount of milk protein equivalent to $0.4 \mathrm{gm}$. $/ \mathrm{kg}$. body weight added to the yeast protein, maximum concentrations of isotope in the urinary ammonia and urea were reached more quickly than in normal subjects and this was considered to result from the more rapid entry of the test materials into the small intestine. From the first study the amount of isotope eliminated in the urine during the first six hours was found to be as high as $10 \%$ of the amount ingested. In normal subjects this value was reasonably constant between 6 and $7 \%$. It is suggested that these high figures indicate considerable malutilization of the absorbed protein since not less than $80 \%$ of the nitrogen of the urine is contained in the urea fraction.

\section{The Effect of the Loss of Pancreatic Secretion on Protein Absorption}

Because of their high activity the loss of the pancreatic enzymes to the body would be expected 
to produce extremely serious nutritional consequences. Cystic disease of the pancreas in children (Clarke and Hadfield, r924) or surgical excision of the pancreas may produce marked weight loss with the appearance of large quantities of fat and nitrogen in the fæces, but in disturbances of pancreatic function following acute or chronic pancreatitis all grades of disability can be encountered, though the finding of markedly increased fæcal nitrogen and fat usually denotes quite severe damage. It is possible that apart from the two conditions mentioned, there is never complete loss of the external secretion of the pancreas. Some estimate of pancreatic insufficiency may be obtained by duodenal intubation of patients after stimulation of the pancreas by secretin or pancreozymin and measuring the concentrations of various enzymes. For trypsin and chymotrypsin, Lundh (1957) has recently introduced a very sensitive method.

West, Wilson and Eyles (1946) fed gelatin to children with deficient pancreatic function and showed that the rise of blood amino-acid nitrogen compared with normal children was extremely depressed, but this situation could be improved by administering pancreatin. Test proteins tagged usually with ${ }^{131} \mathrm{I}$ have been used extensively to investigate pancreatic disease, and Chinn, Lavik, Stitt and Buckaloo (1952) fed ${ }^{131}$ I-labelled albumin to patients with pancreatic disease and showed that the fæcal excretion of the isotope was greater than normal. Freeark, Kozoel and Meyer (1957) showed that the increase of radioactivity appearing in the blood after giving a dose of ${ }^{131}$ I-labelled albumin was low compared with healthy subjects. Polachek and others (1959) carried out a similar investigation on patients with severe pancreatic dysfunction and found identical results for the plasma, but the fæcal excretion in their patients was seldom abnormal. These studies are of diagnostic interest and confirm what would be expected from the loss of pancreatic enzymes by the body, but are, nevertheless, subject to a criticism which has already been discussed. The test protein used is a native one and hence may behave in a different way from the cooked and denatured dietary proteins that are eaten by man.

The disturbance of protein metabolism is much more marked following total pancreatectomy. Whitfield, Gourevitch and Thomas (1952) published a detailed metabolic study on a patient who had a partial gastrectomy and total pancreatectomy. They showed that although fat absorption improved with pancreatin the excretion of nitrogen was not greatly affected and remained between 5 and $8 \mathrm{~g}$. a day on a normal diet. A preliminary communication has already been given (Crane, I96I) on the fate of ${ }^{15} \mathrm{~N}$-yeast protein in this patient who is alive and well I I years after his operation. After three days without supplements of pancreatin it has been shown that this patient did absorb a considerable quantity of his test protein although the absorption was delayed as measured by the rates and extent of labelling of urinary ammonia and urea. These findings in a patient who has lost the benefit of practically all his proteolytic enzymes, thought essential for the digestion of dietary protein, is of some interest. Nakayama and others (1958) have recorded also that in ten patients undergoing combined gastrectomy and pancreatectomy, digestion and absorption of labelled protein, although incomplete, was neverthelsss possible. Handleman, Golden and Pratt (1934) have recorded that dogs deprived of pancreatic secretion can also absorb large quantities of food and that weight loss after operation is regained by excessive dietary intake but fæcal nitrogen losses rise accordingly. More recently Coles (196r) reported that after the occlusion of the pancreatic duct of young cats there was hypertrophy of the small intestinal mucosa and increased proteolytic activity was found but positive evidence on these lines has not yet been obtained for man.

\section{The Absorption of Protein in Coliac Disease}

There has not been much work reported on protein absorption in cœliac disease. In one of the few studies Angfanger and Heavenrich (1949) investigated a series of children with the condition using a test dose of gelatin, and concluded that digestion and uptake were within normal limits. Prior to the publications of Taylor, Wollaeger, Comfort and Power (1952) and Cooke, Thomas, Mangall and Cross (1953) it was generally held that in adult cœliac disease there was little disturbance of nitrogen assimilation, since estimates of fæcal nitrogen were reported as little different from normal values. Further interest in the problem arose from studies by these two groups who showed that considerable losses of nitrogen can nevertheless occur and the observations of Paulley (1954) and Shiner and Doniach (1958) from biopsy specimens that there was often gross pathological change in the jejunal mucosa with partial or complete atrophy of the villi. Crane and Neuberger (I960b and c) fed quantities of ${ }^{15} \mathrm{~N}$-labelled yeast protein and protein hydrolysate to four adult patients with severe cœliac disease and found that the times for maximum labelling of both urinary ammonia and urea (Fig. 3) when whole protein was used were reached between 60 and 90 minutes later than was found for normal subjects (Fig. I). When a hydrolysate was given there was again a delay in maximum labelling (Fig. 4), but this was more 


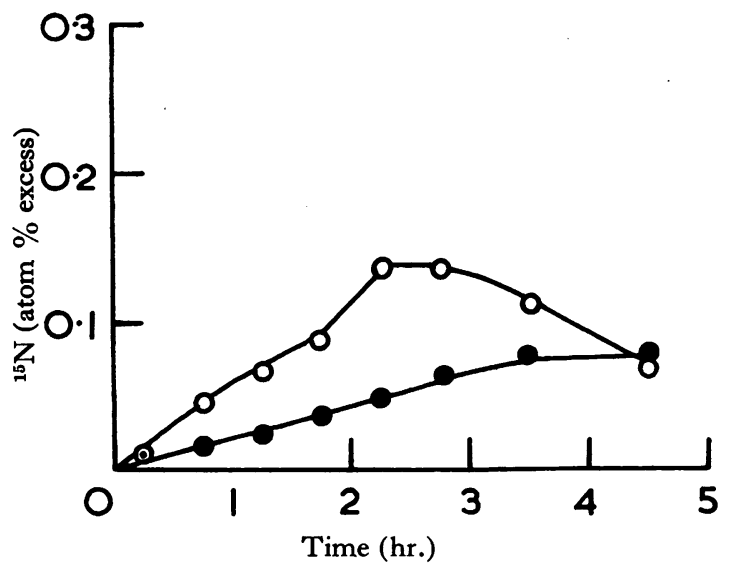

Fig. 3.- ${ }^{15} \mathrm{~N}$ content of urinary ammonia (-o-) and urea (-) after giving labelled whole yeast protein (0.4 mg. ${ }^{15} \mathrm{~N} / \mathrm{kg}$. body weight) mixed with skim milk powder equivalent to $0.4 \mathrm{~g}$. protein $/ \mathrm{kg}$. body weight to a fasting subject. Values are plotted as for Fig. 1 .

variable and considerably less than when whole protein was fed. These results were explained by assuming that while atrophy of the villi of the jejunum reduced its total absorbing surface and hence caused some delay in the uptake of the hydrolysate, the reduced total activity of intracellular peptidases necessitates a greater digestion of the protein by pancreatic enzymes within the lumen of the gut. Analysis of the stool nitrogen for ${ }^{15} \mathrm{~N}$ showed that there was little difference between the amounts of isotope excreted when hydrolysate was substituted for whole protein and that in each case about two-thirds was in a form insoluble in trichloacetic acid indicating a loss of whole protein. It seemed possible, therefore, that this loss of protein, which was larger than that found for normal subjects, could contribute to the hypoalbuminæmia, muscle wasting and negative nitrogen balance often encountered in this disease. In one patient who responded rapidly to withdrawal of gluten from the diet it was found after three weeks that the absorption of labelled protein and the elimination of the isotope in the fæces had returned to normal. In more recent investigations from this laboratory, yet unpublished, it has been found that fæcal losses of isotope may diminish before improvement in absorption and digestion of the labelled protein.

\section{The Absorption of Protein in Massive Resec- tion of the Small Intestine}

Immediately following massive resection of the small bowel for such conditions as mesenteric thrombosis, injury, etc., the body is faced with a sudden decrease in total absorbing area of bowel and mucosal cells capable of elaborating enzymes.

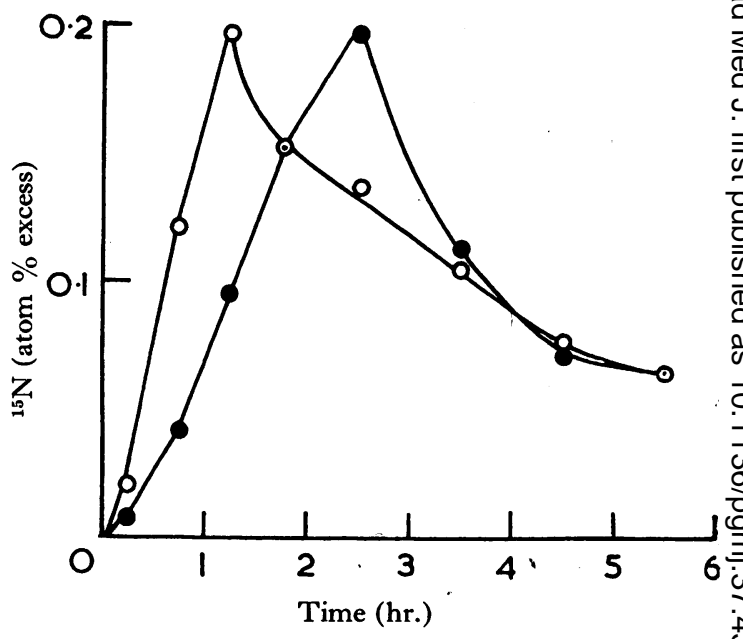

FIG. 4.-Comparison between the ${ }^{15} \mathrm{~N}$ labelling of $\underset{\perp}{\stackrel{\omega}{\oplus}}$ urinary ammonia after giving whole yeast protein $V$ $(-\bullet)$ and hydrolysate (-0-) to a fasting adult patient $\mathrm{c}$ with coliac disease $\left(0.4 \mathrm{mg}\right.$. ${ }^{15} \mathrm{~N} / \mathrm{kg}$. body weight). Values are plotted as for Fig. I.

Experimental work in dogs (Flint, 1912) has shown that up to $50 \%$ of the small bowel can be resected with complete recovery, but in human beings the $\Phi$ disability appears to be more variable. This ma be due to disease in the remaining portions of the gut-for example, Crohn's disease-or formation of blind loops, but Jackson (1958) believes that in the absence of complications the resection of less than two-thirds of the small bowel causes no serious metabolic disturbances. After massive resection large losses of fæcal nitrogen occur; these may be as high as $50 \%$ of the nitrogen intake and amino-acid tolerance tests are abnormal (Althausen, Uyeyama and Simpson, 1949). Perhaps the most striking feature of reported cases is that within a few months of massive resection, bowel movements, initially 20 or so a day, return to normal and patients often regain their pre-operative body weights. Flint (1912) showed that the remaining portion of the small bowel of his dogs underwent considerable hypertrophy with increased size of the villi, and Jackson (1958), summarizing the findings of a number of investigations of patients, reports considerable dilatation and hypertrophy of the remaining portion of the small bowel seen $N$ either at autopsy or on radiological examination, but there was no convincing demonstration of villous hypertrophy. However, from the clinical $\omega$ condition of some of the patients, a considerable compensation in digestion and absorption of protein must take place. Perhaps the dilatation and hypertrophy serve as a functional reservoir by which protein, as has been suggested in adult cœliac disease, may be more thoroughly attacked 
by pancreatic enzymes, or a larger surface area of the villi enables peptides to be more readily absorbed and broken down, but further investigation on these patients is obviously required to elucidate the problem.

It seems likely from the evidence that has been discussed in these few selected topics that the digestion and absorption of dietary protein by man is a more complicated and more rapid affair than would appear from the accounts usually given. In some conditions evidence has been put forward suggesting that some degree of compensation takes place for the loss of particular enzymes or the loss of absorbing surface of the intestine due to surgery or disease. It is hoped that a combination and extension of some of the techniques described will help to eliminate some of the points on which there is at present still some doubt.

I wish to acknowledge with gratitude the support of Professor W. Melville Arnott and Dr. J. M. French of the Department of Medicine, University of Birmingham and of Professor A. Neuberger, Department of Chemical Pathology, St Mary's Hospital, London, in whose Department the earlier ${ }^{15} \mathrm{~N}$ work reported here was carried out. I also wish to thank the United Birmingham Hospitals Endowment Research Fund and the Medical Research Council for financial help.

\section{REFERENCES}

Althausen, T. L., Uyeyama, K., and Simpson, R. G. (1949): Digestion and Absorption after Massive Resection of the Small Intestine, Gastroenterology, 12, 795 .

Angfanger, H., and Heavenrich, R. M. (1949): Aminoacid Tolerance in Children, Amer. F. dis. Child., 77, 425.

AnNis, D., and Hallenbeck, G. A. (1952): The Effects of Partial Gastrectomy on Canine External Pancreatic Secretion, Surgery, 31, 517 .

Avakian, S. (196I): Current Concepts in Therapy: Chymotrypsin and Trypsin, New Engl. f. Med., 264, 764.

Babb, L. I., ChinN, A. B., Stitt, R. M., Lavik, P. S., Levey, S., Kreiger, H., and AbbotT, W. E. (1953): Evaluation of Protein and Fat Metabolism in Postgastrectomy Patients, Arch. Surg., 67, 462.

Bangham, D. R., Ingram, P. L., Roy, J. H. B., Shillam, K. W. G., and TerRY, R. J. (1958): The Absorption of ${ }^{131}$ Ilabelled Serum and Colostral Proteins from the Gut of the Young Calf, Proc. roy. Soc., B 149, 184.

, and Terry, R. J. (1957): The Absorption of ${ }^{131}$ I-labelled Homologous and Heterologous Serum Proteins Fed Orally to Young Rats, Biochem. F., 66, 579.

Bean, W. B., Franklin, M., Embrick, J. F., and Daum, K. (1951): Absorption Studies Using Portal Anastomotic Veins, $\mathcal{F}$. clin. Invest., 30, 263.

BlankenhorN, D. H., Hirsch, J., and Ahrens, E. H. (1955): Transintestinal Intubation Technique for Measurement of Gut Length and Physiologic Samping at Known Loci, Proc. soc. Exp. Biol. (N.Y.), 88, 356.

BoccI, V. (1961): Proteolysis of ${ }^{131}$ I-labelled Gamma Globulin, Int. F. appl. Radiat., ro, 94.

Borgström, B., DahlQvist, A., LundH, G., and Sjövall, J. (1957): Studies of Intestinal Digestion and Absorption in the Human, F. clin. Invest., 36, I521.

CathCart, E. P. (I921): ‘The Physiology of Protein Metabolism'. London: Longmans, Green.

ChinN, A. B., Lavik, P. S., BabB, L. I., Buckaloo, G. W., Stitt, R. M., and ABBotT, W. E. (1953): Blood Isotope Levels following a Test Meal of ${ }^{131}$ I-labelled Protein, F. Lab. clin. Med., 42, 377.

, Stitr, R. M., and Buckaloo, G. W. (1952): Use of ${ }^{131}$ I-labelled Protein in the Diagnosis of Pancreatic Insufficiency, New Engl. F. Med., 247, 877.

Christiansen, H. N., and Shwachman, H. (1949): Determination of the Plasma Glycine after Feeding Gelatin as a Diagnostic Procedure for Pancreatic Fibrosis, f. clin. Invest., 28, 319.

Clarke, C., and Hadfield, G. (1924): Congenital Pancreatic Disease with Infantilism, Quart. F. Med., 17, 358.

Coles, B. L. (196r): Report of Symposium on Small Intestinal Function, Lancet (196r), i, r 342.

Cooke, W. T., ThOMAs, G., MANGALL, D., and CROss, H. (1953): Observations on the Fæcal Excretion of Total Solids, Nitrogen, Sodium, Potassium, Water and Fat in the Steatorrhœea Syndrome, Clin. Sci., 12, 223.

CRANE, C. W. (196r): Report on Symposium on Small Intestinal Function, Lancet, i, 1342.

-, and NeUberGer, A. (1960a): The Digestion and Absorption of Protein by Normal Man, Biochem. F., 74, 313. and Yeast Protein Hydrolysate to Adult Patients with Cœliac Disease: 1 . Rate of Absorption of ${ }^{15} \mathrm{~N}$ Yeast Protein and Yeast Protein Hydrolysate, Brit. med. F., ii, 81 5.

and Yeast Protein Hydrolysate to Adult Patients with Coliac Disease: II. Elimination of the Isotope in the Urine and Fæces, Ibid., ii, 888.

Dent, C. E., and Schilling, J. A. (1949): Studies on the Absorption of Proteins: The Amino-acid Pattern in the Portal Blood, Biochem. F., 44, 318.

Elsom, K. A., CHORNOCK, F. W., and Dickey, F. G. (1942): Intubation Studies of the Human Small Intestine, f. clin. Invest., 21, 795 .

Fisher, R. B. (1954): 'Protein Metabolism'. London: Methuen.

Flint, J. M. (I912): The Effect of Extensive Resection of the Small Intestine, Bull. Fohns Hopk. Hosp., 23, 127.

FREE, A. H., and LeONARDS, J. R. (I944): Studies on the Ingestion of Large Quantities of Protein and Aminoacids, F. Lab. clin. Med., 29, 963 .

FreEark, R. J., KozoEL, D. D., and Meyer, K. A. (1957): The use of ${ }^{131}$ I-labelled Albumin in the Diagnosis of Pancreatic Disease, Surgery, 4I, 268.

Geiger, E. (I947): Experiments with Delayed Supplementation of Incomplete Aminoacid Mixtures, F. Nutr., 34, 97.

, Human, L. E., and Middleton, M. J. (1958): Nitrogen Content of Gastrointestinal Tracts of Rats during Absorptive Period, Proc. Soc. exp. Biol. Med., 97, 232.

Gomez, F., Ramos-Galvan, R., Cravioto, J., and Frenk, S. (1958): Prevention and Treatment of Chronic Severe Infantile Malnutrition (Kwashiorkor), Ann. N.Y. Acad. Sci., 69, 969. 
Gruskay, F. L., and Cooke, R. E. (1955): The Gastrointestinal Absorption of Unaltered Protein in Normal Infants and in Infants Recovering from Diarrhœa, Pediat., r6, 763.

Gupta, J. D., Dakroury, A. M., and Harper, A. E. (1958): Observations on Protein Digestion in vivo, 7. Nutr., 64, 447.

Handleman, M. B., Golden, L. A., and PratT, J. H. (1934): The Effect of Variations in the Diet on the Absorption of Food in the Absence of Pancreatic Digestion, Ibid., 8, 479.

Hokin, L. E. (r9.5 I): Aminoacid Requirements of Amylase Synthesis by Pigeon Pancreas Slices, Biochem. $\mathfrak{F}$., 50, 2 r6.

Jackson, W. P. U. (1958): Massive Resection of the Small Intestine, in 'Modern Trends in Gastroenterology', second series, ed. by Jones, F. A. London: Butterworth.

JANney, N. W. (1915): A Note on the Rate of Metabolism of Protein and Aminoacids, $\mathcal{F}$. biol. Chem., 22, 191.

KEKwICK, R. A. (I959): The Serum Proteins of the Fetus and Young of Some Mammals, 'Advances in Protein Chemistry', vol. 14. New York Academic Press.

KurodA, Y., and Gimbel, N. S. (1954): Selective Disappearance of Aminoacids from the Human Small Intestine, $\mathcal{Y}$. appl. Physiol., 7, 148 .

Lavik, P. S., MatrHews, L. W., Spector, S., and Friedell, H. (1952): Utilization of ${ }^{131}$ I-labelled Casec in the Study $\vec{\odot}$ of Protein Digestion and Absorption, Amer. Y. dis. Child., 84, 736.

Leblond, C. P., and Stevens, C. E. (1948): The Constant Renewal of the Intestinal Epithelium in the Albino Rat, Anat. Rec., roo, 357.

Linderstrom-Lang, K. U. (I952): ' Lane Medical Lectures: Proteins and Enzymes'. California: Stanford University Press.

LuNDH, G. (1957): Determination of Trypsin and Chymotrypsin in Human Intestinal Contents, Scand. F. clin. Lab. Invest., 9, 229.

- (1958): Intestinal Digestion and Absorption after Gastrectomy, Acta chir. scand., Suppl. 23 I.

LusK, G. (1928): 'The Elements of the Science of Nutrition', fourth edition. London: Saunders.

McGee, L. C., and EMery, E. S. (1940): Rate of Absorption of Aminoacids from the Small Intestine of Man, Proc Soc. exp. Biol. Med., 45, 475.

Nakayama, K., Ohtsuka, A., Kuvaishi, T., Koshibu, M., Arima, M., Fukushima, M., Nakagami, T., and Fuse, S. (1958): 'Study of Digestion and Absorption with Radioactive Isotopes following Gastrointestinal Surgery: Isotopes in Medicine '. Geneva: United Nations.

Nasset, E. S. (1957): The Role of the Digestive Tract in the Utilization of Protein and Aminoacids, F. Amer. med. Ass., $164,172$.

- and Davenport, A. (1954): Canine and Human Digestion of Proteins in vivo, F. appl. Physiol., 7, 447.

Newey, H., and Smyth, D. H. (1959): The Intestinal Absorption of Some Di-peptides, $\mathcal{F}$. Physiol., I45, 48.

Parish, W. E., Barrett, A. M., Coombs, R. R. A., Gunther, M., and Camps, F. E. (I96o): Hypersensitivity to Milk and Sudden Death in Infancy, Lancet, ii, 1 Io6.

Paulley, J. W. (1954): Observations on the Ætiology of Idiopathic Steatorrhœa, Brit. med. F., ii, I318.

PolacheK, A. A., Cope, C. B., Williard, R. F., and Barnes, F. W. (1959): ${ }^{131}$ I-labelled Protein and Fat Meals ir Patients with Chronic Pancreatitis, Gastroenterology, 37, 38.

Reifenstein, E. C., Albright, F., and Wells, S. L. (1945): The Accumulation, Interpretation and Presentation of Data Pertaining to Metabolic Balances, Notably Those of Calcium, Phosphorus and Nitrogen, $\boldsymbol{F}$. clin. Endocr., 5, 367.

Scrimshaw, N. S., Brissani, R., Behar, M., and Viteri, F. (1958): Supplementation of Cereal Proteins with Aminoacids, $\mathcal{F}$. Nutr., 66, 485 .

Sharpe, G. S., Lassen, S., Shankman, S., Gebhart, A. F., and Hazlet, J. W. (1956): Studies of Protein Absorption Using Nitrogen 15 as a Tag, Ibid., 58, 443 .

Shiner, M., and Doniach, I. (1958): Histopathologic Studies in Steatorrhœe, Proc. World Congr. of Gastroenterology, Washington, 1958, r, 586. Baltimore: Williams and Wilkins.

TAYLOR, W. H. (1959a): Studies on Gastric Proteolysis, I, Biochem. F., 7r, 73.

(1959b): Gastric Proteolysis in Disease, I, F. clin. Path., 12, 2 10.

Taylor, A. B., Wollaeger, E. E., Comfort, M. W., and Power, M. H. (1952): The Effect of Cortisone on Nontropical Sprue, Gastroenterology, 20, 203.

West, C. D., Wilson, J. L., and EyLes, R. (1946): Changes in Blood Amino Nitrogen Levels following Ingestion of Protein and of a Protein Hydrolysate in Infants with Normal and with Deficient Pancreatic Function, Amer. $\mathcal{Y}$. dis. Child., 72, $25 \mathrm{I}$.

Whitfield, A. G. W., Gourevitch, A., and Thomas, G. (1952): Metabolic Effects of Total Pancreatectomy in Man, Lancet, i, 180 .

White, A. G. C., and Parson, W. (1950): Comparative Studies on Nitrogen Excretion, Arch. Biochem., 26, 205.

Wilson, S. J., and Walzer, M. (1935): Absorption of Unaltered Egg Protein in Infants and Children, Amer. F. dis. Child., 50, 49.

Wright, R. D., Jennings, M. A., Florey, H. W., and LiUm, R. (1940): The Influence of Nerves and Drugs on Secretion by the Small Intestine and an Investigation of the Enzymes in the Intestinal Juice, Quart. F. exp. Physiol., 30, 73.

—, and Wynn, V. (1951): The Digestion of Protein in the Alimentary Canal, Aust. Y. exp. Biol. med. Sci., 29, 28 I. 